РОЗ В ЕДЕННЯ ТАГЕН Е И КА

УДК 636.2.034.082

doi: $10.36359 /$ scivp.2019-20-2.47

\title{
ЕКСТЕР’СРНІ ОСОБЛИВОСТІ КОРІВ-ПЕРВІСТОК УКРАЇНСЬКОЇ ЧОРНО- ТА ЧЕРВОНО-РЯБОЇ МОЛОЧНИХ ПОРІД І ЇХ ПОМІСЕЙ 3 ДЖЕРСЕЯМИ
}

\author{
О. В. Малиновська, аспірант ${ }^{1}$ \\ C. I. Федорович, д-р с.-г. наук, професор \\ M. I. Кузів, д-р с.-г. наук, с. н..$^{2}$
}

${ }^{1}$ Інститут розведення і генетики тварин імені М. В. Зубця НААН, вул. Погребняка, 1, с. Чубинське Бориспільського району Київської області, 08321, Україна

${ }^{2}$ Інститут біології тварин НААН, вул. В. Стуса, 38, м. Львів, 79034, Україна

Наведено дані щодо промірів та індексів будови тіла корів української чорно- та червоно-рябої молочних порід $і$ їх потомків першого й другого поколінь з часткою спадковості джерсеїв 50 i $75 \%$. Встановлено, шуо корови-первістки украйнської чорно-рябої молочної породи переважали за досліджуваними промірами (виняток - иирина грудей) цільові параметри для тварин бажсаного типу, а української червоно-рябої молочної породи переважали ці параметри за глибиною грудей, шириною в маклаках та обхватом п'ястка $i$ поступалися їм за висотою в холиі, шириною грудей, обхватом грудей за лопатками та косою довжсиною тулуба. Із збільшенням частки спадковості джерсеӥв у генотипі тварин української чорно- та червоно-рябої молочних порід проміри тіла зменшувалися. 3 а більшістю індексів будови тіла піддослідні корови переважали свойх потомків першої і другої генерацій. Причому більш суттева різниця між вихідним маточним поголів'ям та їх помісними нащадками з джерсеями першого й другого поколінь була відмічена у корів української червоно-рябої молочної породи. Досліджувані нами проміри та індекси будови тіла свідчать про явно виражений молочний напрям продуктивності не лише корів украӥнськоӥ чорно- та червоно-рябої молочних порід, але й їх помісей з часткою спадковості джерсеїв 50 і $75 \%$.

Ключові слова: УКРАЇНСЬКА ЧОРНО-РЯБА МОЛОЧНА ПОРОДА, УКРАЇНСЬКА ЧЕРВОНО-РЯБА МОЛОЧНА ПОРОДА, ПОМІСІ, КОРОВИ-ПЕРВІСТКИ, ПРОМІРИ ТІЛА, ІНДЕКСИ БУДОВИ ТІЛА.

Продуктивні й племінні якості тварин найбільш повно характеризує їх комплексна оцінка, важливим складовим елементом якої є оцінка екстер'єру. Добре виражена породна типовість 3 характерними показниками розвитку статей тіла корів значною мірою зумовлює високі показники продуктивних і виступає певним мірилом адаптаційних якостей [1-4]. Селекція молочної худоби у світі грунтується на врахуванні двох основних ознак - молочній продуктивності та екстер'єрному типі тварин [5]. На сьогоднішній час, коли продуктивність корів у країнах з розвинутим молочним скотарством перейшла рубіж вісім-десять тисяч кілограмів молока за лактацію, пріоритетним напрямом селекції стало отримання тварин 
міцного екстер'єрно-конституційного типу, який здатний забезпечити їх тривале продуктивне довголіття $[5,6]$.

У скотарстві України найбільшого поширення набула інструментальна оцінка екстер'єру тварин $з$ використанням спеціальних вимірювальних засобів. Така оцінка дає об'єктивні дані не лише про окрему особину, а й про групи тварин та породи в цілому [7]. Відомо, що худоба різних порід та різних генотипів відрізняються між собою за типом будови тіла. 3 огляду на зазначене, метою наших досліджень було вивчити екстер'єр корів-первісток української чорно- та червоно-рябої молочних порід і їх помісей першого й другого поколінь з плідниками джерсейської породи.

Матеріали і методи. Дослідження на коровах-первістках української чорно-рябої молочної породи (УЧРМ) і їх помісях 3 джерсеями першого (1/2УЧРМ×1/2Д) й другого (1/4УЧРМ×3/4Д) поколінь проведені в ФГ «Елітмілк» Кам'янко-Бузького району, а на первістках української червоно-рябої молочної породи (УЧеРМ) і їх помісях 3 джерсеями

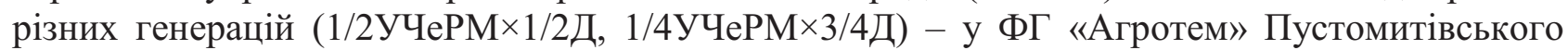
району Львівської області.

Екстер'єр тварин маточного поголів'я та потомків першого покоління оцінювали за даними первинного зоотехнічного обліку, а потомків другого покоління - шляхом вимірювання статей тіла. За допомогою мірних стрічки, циркуля і палиці брали наступні проміри: висота в холці, глибина і ширина грудей, обхват грудей за лопатками, коса довжина тулуба, ширина в маклаках та обхват п'ястка. Шляхом співвідношення відповідних промірів вираховували індекси будови тіла тварин [8].

Статистичну обробку одержаних даних проводили за методикою Г. Ф. Лакина [9] 3 використанням комп’ ютерних програм «Excel» та «Statistica 6.1». Результати середніх значень вважали статистично вірогідними при $\mathrm{P}<0,05$ (*), $\mathrm{P}<0,01$ (**), $\mathrm{P}<0,001$ (***).

Результати й обговорення. Встановлено, що корови-первістки української чорнорябої молочної породи порівняно 3 їх помісями 3 джерсеями відзначалися більшою високорослістю, розтягнутістю, у них були більші ширина й глибина грудей, обхват грудей за лопатками, ширина в маклаках та грубший кістяк (табл. 1). Із збільшенням частки спадковості джерсеїв у генотипі тварин української чорно-рябої молочної породи проміри тіла тварин зменшувалися. Так, первістки української чорно-рябої молочної породи за висотою в холці переважали потомків генотипів 1/2УЧРМ×1/2Д і 1/4УЧРМ×3/4Д на 2,4 і 5,6 (P<0,001), за глибиною грудей - на 1,8 і 4,6 (P<0,01), за шириною грудей - на 2,3 (P<0,05) і 3,9 $(\mathrm{P}<0,01)$, за обхватом грудей за лопатками - на 5,2 (P<0,05) і 14,2 (P<0,001), за косою довжиною тулуба на 4,7 ( $<<0,05)$ i 10,1 (P<0,001) за шириною в маклаках - на 1,8 і 4,3 (P<0,001) та за обхватом п’ястка - на 0,6 (P<0,01) і 1,1 см (P<0,001) відповідно. При порівнянні помісей досліджуваних генерацій між собою напівкровні тварини за всіма досліджуваними промірами тіла вірогідно $(\mathrm{P}<0,05, \mathrm{P}<0,001)$ переважали особин $з$ часткою спадковості джерсеїв 75 \% (виняток - ширина грудей).

Таблиия 1

Проміри тіла корів-первісток української чорно-рябої молочної породи та їх помісей 3 джерсеями, см

\begin{tabular}{|c|c|c|c|c|c|c|}
\hline \multirow{2}{*}{ Показники } & \multicolumn{2}{|c|}{ УЧРМ } & \multicolumn{2}{|c|}{$1 / 2 У Ч Р М × 1 / 2 Д$} & \multicolumn{2}{|c|}{$1 / 4$ УЧРМ×3/4Д } \\
\hline & $\mathrm{M} \pm \mathrm{m}$ & $\mathrm{C}_{\mathrm{v}} \%$ & $\mathrm{M} \pm \mathrm{m}$ & $\mathrm{C}_{\mathrm{v},} \%$ & $\mathrm{M} \pm \mathrm{m}$ & $\mathrm{C}_{\mathrm{v}}, \%$ \\
\hline Висота в холці & $133,1 \pm 0,88$ & 2,5 & $130,7 \pm 0,95$ & 2,7 & $127,5 \pm 0,81 * * *$ & 2,4 \\
\hline Глибина грудей & $73,2 \pm 0,90$ & 4,6 & $71,4 \pm 0,92$ & 4,8 & $68,6 \pm 0,94 * *$ & 5,1 \\
\hline Ширина грудей & $44,7 \pm 0,84$ & 7,1 & $42,4 \pm 0,79 *$ & 6,9 & $40,8 \pm 0,88^{* *}$ & 8,0 \\
\hline Обхват грудей за лопатками & $192,1 \pm 1,64$ & 3,2 & $186,9 \pm 1,65^{*}$ & 3,3 & $177,9 \pm 1,54 * * *$ & 3,2 \\
\hline Коса довжина тулуба & $157,6 \pm 1,47$ & 3,5 & $152,9 \pm 1,46^{*}$ & 3,6 & $147,5 \pm 1,48 * * *$ & 3,8 \\
\hline Ширина в маклаках & $52,5 \pm 0,73$ & 5,2 & $50,7 \pm 0,81$ & 5,9 & $48,2 \pm 0,75^{* * *}$ & 5,8 \\
\hline Обхват п’ястка & $18,0 \pm 0,16$ & 3,4 & $17,4 \pm 0,12 * *$ & 2,6 & $16,9 \pm 0,18 * * *$ & 4,0 \\
\hline
\end{tabular}

Примітка: у цій таблиці та таблиці 3 достовірність різниці показників вказана при порівнянні до тварин

української чорно-рябої молочної породи (УЧРМ). 
Слід зазначити, що зменшення промірів у помісей першого й другого поколінь, порівняно 3 чистопородними первістками української чорно-рябої молочної породи, коливалося від 1,8 до 5,1 та від 4,2 до 8,7 \% відповідно, причому у тварин обох генотипів найбільше зменшилася ширина грудей, а найменше - висота в холці. Вузькогрудість помісей, очевидно, пояснюється успадковуваністю цього показника від бугаїв-плідників джерсейської породи, які, як відомо, за шириною грудей поступаються тваринам інших спеціалізованих молочних порід. Дещо нижчими показниками ширини грудей порівняно зі стандартом породи характеризувалися й первістки української чорно-рябої молочної породи, що обумовлено високою спадковістю у їх генотипі голштинських плідників, яким також притаманна вузькогрудість. За іншими промірами вони переважали цільові параметри для тварин бажаного типу [10]. Водночас помісі обох генерацій за досліджуваними промірами поступалися цим параметрам (виняток - висота в холці у тварин генотипу $1 / 2$ УЧРМ×1/2Д).

За промірами екстер'єру корови-первістки української червоно-рябої молочної породи також переважали своїх помісних нащадків 3 джерсеями першого й другого поколінь, причому ця перевага, за винятком косої довжини тулуба у тварин генотипу $1 / 2$ УЧеРМ×1/2Д, у всіх випадках була вірогідною $(\mathrm{P}<0,05-0,001)$. У свою чергу первістки першої генерації вірогідно $(\mathrm{P}<0,01)$ переважали особин другої генерації за висотою в холці, глибиною й шириною грудей, обхватом грудей за лопатками та косою довжиною тулуба і невірогідно - за шириною в маклаках та обхватом п'ястка.

Таблиия 2

Проміри тіла корів-первісток української червоно-рябої молочної породи та їх помісей 3 джерсеями, см

\begin{tabular}{|c|c|c|c|c|c|c|}
\hline \multirow{2}{*}{ Показники } & \multicolumn{2}{|c|}{ УЧеРМ } & \multicolumn{2}{|c|}{ 1/2УЧеРМ×1/2Д } & \multicolumn{2}{|c|}{ 1/4УЧеРМ×3/4Д } \\
\hline & $\mathrm{M} \pm \mathrm{m}$ & $\mathrm{C}_{\mathrm{v},} \%$ & $\mathrm{M} \pm \mathrm{m}$ & $\mathrm{C}_{\mathrm{v},}, \%$ & $\mathrm{M} \pm \mathrm{m}$ & $\mathrm{C}_{\mathrm{v}}, \%$ \\
\hline Висота в холці & $135,2 \pm 0,78$ & 2,6 & $131,9 \pm 0,60 * *$ & 1,7 & $129,1 \pm 0,65^{* * *}$ & 1,9 \\
\hline Глибина грудей & $75,1 \pm 0,81$ & 4,0 & $72,1 \pm 0,75^{* *}$ & 3,9 & $69,0 \pm 0,69 * * *$ & 3,7 \\
\hline Ширина грудей & $47,9 \pm 0,85$ & 6,6 & $44,1 \pm 0,53 * * *$ & 4,5 & $41,5 \pm 0,74 * * *$ & 6,7 \\
\hline Обхват грудей за лопатками & $195,5 \pm 1,69$ & 3,2 & $189,2 \pm 1,93 *$ & 3,8 & $180,4 \pm 1,84 * * *$ & 3,8 \\
\hline Коса довжина тулуба & $160,7 \pm 1,48$ & 3,4 & $157,5 \pm 1,39$ & 3,3 & $151,9 \pm 1,29 * * *$ & 3,2 \\
\hline Ширина в маклаках & $54,6 \pm 0,73$ & 5,0 & $52,3 \pm 0,83^{*}$ & 6,0 & $50,5 \pm 0,81 * * *$ & 6,0 \\
\hline Обхват п’ястка & $19,1 \pm 0,21$ & 4,1 & $18,0 \pm 0,12 * * *$ & 2,6 & $17,7 \pm 0,13 * * *$ & 2,8 \\
\hline
\end{tabular}

Примітка: У цій та таблиці 4 достовірність різниці показників вказана при порівнянні до тварин української червоно-рябої молочної породи (УЧеРМ).

Слід відмітити, що у тварин генотипів 1/2УЧеРМ×1/2Д та 1/4УЧеРМ×3/4Д, порівняно 3 вихідним маточним поголів'ям української червоно-рябої молочної породи, висота в холці зменшилася на 2,4 та 4,5, глибина грудей - на 4,0 та 8,1, ширина грудей - на 7,9 та 13,4, обхват грудей за лопатками - на 3,2 та 7,3, коса довжина тулуба - на 2,0 та 5,5, ширина в маклаках на 4,2 та 7,5 і обхват п'ястка - на 5,8 та 7,3 \% відповідно.

Встановлено, що первістки української червоно-рябої молочної породи поступалися цільовим параметрам будови тіла корів бажаного типу [11] за висотою в холці, шириною грудей, обхватом грудей за лопатками та косою довжиною тулуба і переважали ці параметри за глибиною грудей, шириною в маклаках та обхватом п’ястка. Помісі обох генотипів за всіма досліджуваними промірами тіла поступалися цільовим параметрам будови тіла бажаного типу для корів української червоно-рябої молочної породи.

Більш повне уявлення про екстер'єр худоби у співвідносному розвиту статей, пропорційність або дисгармонію їх розвитку дають індекси будови тіла тварин. Встановлено, що за індексом довгоногості, розтягнутості, тазо-грудним, збитості, костистості, вираженості типу, індексом статі, округлості ребер, глибокогрудості та широкогрудості не відмічено достовірної різниці між тваринами досліджуваних груп, однак за більшістю досліджуваних індексів вищими показниками відзначалися первістки української чорно-рябої молочної породи і лише за індексами збитості та індексом статті - помісі першого покоління та за індексами довгоногості й ейрисомії-лептосомії - помісі другого покоління (табл. 3). 
Варто вказати, що вищі показники грудного індексу, глибокогрудості, широкогрудості та тазо-грудного у первісток української чорно-рябої молочної породи свідчать про кращий розвиток їх грудної клітини порівняно з потомками першого й другого поколінь. Більша величина індексу збитості у корів-первісток з часткою спадковості джерсеїв 50 \% порівняно 3 тваринами інших двох груп вказує на краще виражений у них розвиток будови тіла.

Таблиия 3

Індекси будови корів-первісток української чорно-рябої молочної породи й їх помісей з джерсеями, \% $(\mathbf{n}=15)$

\begin{tabular}{|l|c|c|c|c|c|c|}
\hline \multirow{2}{*}{\multicolumn{1}{|c|}{ Показники }} & \multicolumn{2}{|c|}{ УЧРМ } & \multicolumn{2}{c|}{$1 / 2$ УЧРМ×1/2Д } & \multicolumn{2}{c|}{$1 / 4$ УЧРМ×3/4Д } \\
\cline { 2 - 7 } & $\mathrm{M} \pm \mathrm{m}$ & $\mathrm{Cv}, \%$ & $\mathrm{M} \pm \mathrm{m}$ & $\mathrm{Cv}, \%$ & $\mathrm{M} \pm \mathrm{m}$ & $\mathrm{Cv}, \%$ \\
\hline Довгоногості (високоногості) & $45,0 \pm 0,53$ & 4,6 & $45,4 \pm 0,52$ & 4,4 & $46,2 \pm 0,55$ & 4,6 \\
\hline Розтягнутості (формату) & $118,4 \pm 1,10$ & 3,6 & $117,0 \pm 1,11$ & 3,7 & $115,7 \pm 1,00$ & 3,4 \\
\hline Грудний & $61,0 \pm 0,56$ & 3,6 & $59,3 \pm 0,54^{*}$ & 3,5 & $59,4 \pm 0,73$ & 4,8 \\
\hline Тазо-грудний & $85,0 \pm 0,64$ & 2,9 & $83,7 \pm 0,66$ & 3,0 & $84,6 \pm 0,90$ & 4,1 \\
\hline Збитості & $121,9 \pm 1,05$ & 3,3 & $122,3 \pm 1,16$ & 3,7 & $120,7 \pm 1,03$ & 3,3 \\
\hline Костистості & $13,6 \pm 0,13$ & 3,7 & $13,4 \pm 0,11$ & 3,3 & $13,3 \pm 0,15$ & 4,4 \\
\hline Масивності & $144,3 \pm 0,69$ & 1,8 & $142,9 \pm 0,75$ & 2,0 & $139,5 \pm 0,68^{* * *}$ & 1,9 \\
\hline Масивності за Дюрстом & $518,5 \pm 19,26$ & 14,4 & $465,7 \pm 17,28^{*}$ & 14,4 & $415,8 \pm 16,95^{* * *}$ & 15,8 \\
\hline Ейрисомії & $33,4 \pm 0,33$ & 3,8 & $32,8 \pm 0,33$ & 3,9 & $32,3 \pm 0,35^{*}$ & 4,2 \\
\hline Лептосомії & $73,0 \pm 1,01$ & 5,4 & $71,2 \pm 1,00$ & 5,4 & $69,8 \pm 1,01 *$ & 5,6 \\
\hline Ейрисомії-лептосомії & $299,7 \pm 2,90$ & 3,7 & $305,4 \pm 3,12$ & 4,0 & $309,7 \pm 3,42^{*}$ & 4,3 \\
\hline Вираженості типу & $22,2 \pm 0,23$ & 4,1 & $21,8 \pm 0,24$ & 4,2 & $21,7 \pm 0,28$ & 5,1 \\
\hline Індекс статі & $117,8 \pm 0,87$ & 2,9 & $119,6 \pm 0,91$ & 3,0 & $118,4 \pm 1,26$ & 4,1 \\
\hline Округлості ребер & $131,3 \pm 1,17$ & 3,4 & $131,0 \pm 1,29$ & 3,8 & $129,8 \pm 1,19$ & 3,6 \\
\hline Глибокогрудості & $55,0 \pm 0,53$ & 3,7 & $54,6 \pm 0,52$ & 3,7 & $53,8 \pm 0,55$ & 4,0 \\
\hline Широкогрудості & $33,5 \pm 0,54$ & 6,3 & $32,4 \pm 0,49$ & 5,8 & $32,0 \pm 0,57$ & 6,9 \\
\hline
\end{tabular}

Найменші значення індексу костистості у нащадків другої генерації свідчать про тонший кістяк у них, ніж у їх матерів та матерів їх матерів.

Більш чітко була виражена міжгрупова диференціація за індексами будови тіла у тварин української червоно-рябої молочної породи та їх помісних нащадків 3 джерсеями першого і другого поколінь (табл. 4).

Таблиия 4

Індекси будови тіла корів-первісток української червоно-рябої молочної породи та їх помісей з джерсеями, \% (n=15)

\begin{tabular}{|c|c|c|c|c|c|c|}
\hline \multirow{2}{*}{ Показники } & \multicolumn{2}{|c|}{ УЧеРМ } & \multicolumn{2}{|c|}{$1 / 2$ УЧеРМ×1/2Д } & \multicolumn{2}{|c|}{$1 / 4 \mathrm{УЧеРМ×3/4Д}$} \\
\hline & $\mathrm{M} \pm \mathrm{m}$ & $\mathrm{Cv}, \%$ & $\mathrm{M} \pm \mathrm{m}$ & $\mathrm{Cv}, \%$ & $\mathrm{M} \pm \mathrm{m}$ & $\mathrm{Cv}, \%$ \\
\hline Довгоногості (високоногості) & $44,4 \pm 0,43$ & 3,7 & $45,3 \pm 0,34$ & 2,9 & $46,6 \pm 0,31^{* * *}$ & 2,6 \\
\hline Розтягнутості (формату) & $118,8 \pm 1,02$ & 3,3 & $119,3 \pm 0,57$ & 1,8 & $117,6 \pm 0,45$ & 1,5 \\
\hline Грудний & $63,7 \pm 0,52$ & 3,2 & $61,1 \pm 0,29 * * *$ & 1,8 & $60,1 \pm 0,53 * * *$ & 3,4 \\
\hline Тазо-грудний & $87,7 \pm 0,56$ & 2,5 & $84,4 \pm 0,53 * * *$ & 2,4 & $82,3 \pm 0,75^{* * *}$ & 3,5 \\
\hline Збитості & $121,7 \pm 1,01$ & 3,2 & $120,1 \pm 0,48$ & 1,6 & $118,8 \pm 0,90^{*}$ & 2,9 \\
\hline Костистості & $14,1 \pm 0,12$ & 3,4 & $13,6 \pm 0,05 * * *$ & 1,4 & $13,7 \pm 0,09^{* *}$ & 2,6 \\
\hline Масивності & $144,6 \pm 0,75$ & 2,0 & $143,4 \pm 0,92$ & 2,5 & $139,7 \pm 1,04 * * *$ & 2,9 \\
\hline Масивності за Дюрстом & $581,8 \pm 20,16$ & 13,4 & $502,5 \pm 14,77 * *$ & 11,4 & $437,4 \pm 14,85^{* * *}$ & 13,2 \\
\hline Ейрисомії & $34,6 \pm 0,32$ & 3,5 & $33,3 \pm 0,26^{* *}$ & 3,0 & $32,7 \pm 0,32 * * *$ & 3,8 \\
\hline Лептосомії & $75,8 \pm 0,98$ & 5,0 & $73,0 \pm 0,72 *$ & 3,8 & $71,2 \pm 0,83 * * *$ & 4,5 \\
\hline Ейрисомії-лептосомії & $289,1 \pm 2,62$ & 3,5 & $300,8 \pm 2,29 * * *$ & 3,0 & $306,1 \pm 2,95^{* * *}$ & 3,7 \\
\hline Вираженості типу & $23,4 \pm 0,22$ & 3,6 & $22,0 \pm 0,12 * * *$ & 2,1 & $21,4 \pm 0,21 * * *$ & 3,8 \\
\hline Індекс статі & $114,0 \pm 0,73$ & 2,5 & $118,6 \pm 0,72 * * *$ & 2,3 & $121,6 \pm 1,11^{* * *}$ & 3,5 \\
\hline Округлості ребер & $130,2 \pm 1,00$ & 3,0 & $131,1 \pm 0,53$ & 1,6 & $130,8 \pm 0,89$ & 2,6 \\
\hline Глибокогрудості & $55,6 \pm 0,43$ & 3,0 & $54,7 \pm 0,34$ & 2,4 & $53,4 \pm 0,31 * * *$ & 2,2 \\
\hline Широкогрудості & $35,4 \pm 0,53$ & 5,7 & $33,4 \pm 0,28^{* * *}$ & 3,2 & $32,1 \pm 0,41 * * *$ & 4,9 \\
\hline
\end{tabular}


Так, за більшістю досліджуваних індексів перші вірогідно $(\mathrm{P}<0,05-0,001)$ переважали своїх потомків обох генерацій і лише за індексами статі й округлості ребер перевага була на боці напівкровних помісей та за індексами довгоногості й ейрисомії-лептосомії - на боці особин з часткою спадковості джерсейської породи $75 \%$.

Таким чином, вирахувані нами індекси будови тіла свідчать про явно виражений молочний напрям продуктивності не лише корів української чорно- та червоно-рябої молочних порід, але й їх помісей з часткою спадковості 50 і 75 \%.

\title{
В И С Н О В К И
}

1. Корови-первістки української чорно-рябої молочної породи переважали за досліджуваними промірами (виняток - ширина грудей) цільові параметри для тварин бажаного типу, а української червоно-рябої молочної породи переважали ці параметри за глибиною грудей, шириною в маклаках та обхватом п'ястка і поступалися їм за висотою в холці, шириною грудей, обхватом грудей за лопатками та косою довжиною тулуба.

2. Із збільшенням частки спадковості джерсеїв у генотипі тварин української чорно- та червоно-рябої молочних порід проміри тіла зменшувалися.

3. За індексами будови тіла більш суттєва різниця між вихідним маточним поголів’ям та їх помісними нащадками 3 джерсеями першого й другого поколінь була відмічена у корів української червоно-рябої молочної породи.

4. Індекси будови тіла свідчать про явно виражений молочний напрям продуктивності не лише корів української чорно- та червоно-рябої молочних порід, але й їх помісей з часткою спадковості джерсеїв 50 і $75 \%$.

Перспективи досліджень. У подальшому буде вивчено вплив промірів тіла на формування молочної продуктивності у корів української чорно- та червоно-рябої молочних порід і їх помісей з джерсеями.

\section{EXTERNAL FEATURES OF HEIFERS OF UKRAINIAN BLACK-AND RED-AND-WHITE DAIRY BREES AND THEIR CROSS BREEDS WITH JERSEY}

\author{
O. V. Malynovska', Ye. I. Fedorovych ${ }^{2}$, M. I. Kuziv ${ }^{2}$ \\ ${ }^{1}$ Institute of Animal Breeding and Genetics named after M.V. Zubets NAAS, \\ Kyiv district, Chubynske village, Pogrebnyak Street 1, 08231, Ukraine, \\ ${ }^{2}$ Institute of Animal Biology NAAS, \\ V. Stus Street 38, Lviv, 79034, Ukraine,
}

\section{S U M M A R Y}

The cattle breeding in Ukraine has become the most widely used instrumental assessment of the exterior of animals using special measuring instruments. Such an estimate provides objective data not only about an individual, but also about groups of animals and breed in general. It is known that animals of different breeds and different genotypes differ in their type of body structure. In view of the above, the purpose of our research was to study the exterior of the first-born cows of the Ukrainian Black-and-White and Red-and-White breeds and their ranges of the first and second generations with the breeders of the Jersey breed. Studies on the first cows of the Black-and-White milk breed and their intercourse with the first and second generation of Jersey were carried out in the farm "Elitmilk" of the Kamianko-Buzky district, and on the first-fruits of the Ukrainian Red-and-White dairy breed and their intercourse with Jersey of various generations in farm "Agrotem" of Pustomyty district of Lviv region. 
It was established that the first-born cows of Ukrainian Black-and-White milk breed dominated by the measurable measurements (exception - breast width) target parameters the animals of desired type, and the Ukrainian Red-and-White dairy breed prevailed for these parameters by the depth of the chest, the width of the maclakes, and the girth of the fifth and inferior to them in height of shoulders, the width of the breast, the chest covering of the shoulder blades and the oblique length of the trunk. With the increase of the proportion of heredity of Jersey in the genotype of Black and Red-and-White animals breast milk body measurements diminished. In most of the body structure indices, the experimental cows dominated their descendants first and second generations. Between the initial breeding stock and their interbreed descendants from the Jersey of the first and second generations a more significant difference was noted between the various groups of cows of Ukrainian Red-and-White breed than Ukrainian Black-and-White dairy breed.

The measurements and indices of the structure of the body clearly pronounced the milk productivity potential of not only cows of the Ukrainian Black and Red-and-White dairy breeds, but also their cross breed with a proportion of heredity of Jersey 50 and $75 \%$.

Keywords: UKRAINIAN BLACK-AND-WHITE DAIRY BREED; UKRAINIAN REDAND-WHITE DAIRY BREED, CROSS BREEDS, HEIFERS, BODY MEASUREMENTS, BODY STRUCTURE INDICES.

\title{
ЭКСТЕРЬЕРНЫЕ ОСОБЕННОСТИ КОРОВ-ПЕРВОТЕЛОК УКРАИНСКОЙ ЧЕРНО- И КРАСНО-ПЕСТРОЙ МОЛОЧНОЙ ПОРОД И ИХ ПОМЕСЕЙ С ДЖЕРСЕЯМИ
}

\author{
А. В. Малиновская ${ }^{1}$ Е. И. Федорович ${ }^{2}$ М. И. Кузив ${ }^{2}$
}

${ }^{1}$ Институт разведения и генетики животных имени М. В. Зубца НААН, ул. Погребняка, 1, с. Чубинское Бориспольского района Киевской области, 08321, Украина

${ }^{2}$ Институт биологии животных НААН, ул. В. Стуса, 38, г. Львов, 79034, Украина

\section{А Н Н О Т А ЦИ Я}

Приведены даные по промерам и индексам телосложения коров украинской черно- и красно-пестрой молочных пород и их потомков с долей наследственности джерсеев 50 и 75 \%. Установлено, что коровы-первотелки украинской черно-пестрой молочной породы превосходили по исследуемым промерам (исключение - ширина груди) целевые параметры для животных желательного типа, а украинской красно-пестрой молочной породы преобладали эти параметры по глубине груди, ширине в маклаках и обхвату пястка и уступали им по высоте в холке, ширине груди, обхвату груди за лопатками и косой длинне туловища. С увеличением доли наследственности джерсеев в генотипе животных черно- и красно-пестрой молочных пород промеры тела уменьшались.

По большинству индексов телосложения подопытные коровы превосходили своих потомков первой и второй генераций. Причем более существенная разница между исходным маточным поголовьем и их поместными потомками с джерсеямы первого и второго поколений была отмечена у коров украинской красно-пестрой молочной породы.

Исследуемые нами промеры и индексы телосложения свидетельствуют о явно выраженном молочном направление продуктивности не только коров украинской черно- и красно-пестрой молочных пород, но и их помесей с долей наследственности джерсеив 50 и $75 \%$.

Ключевые слова: УКРАИНСКАЯ ЧЕРНО-ПЕСТРАЯ МОЛОЧНАЯ ПОРОДА, УКРАИНСКАЯ КРАСНО-ПЕСТРАЯ МОЛОЧНАЯ ПОРОДА, КОРОВЫ-ПЕРВОТЕЛКИ, ПРОМЕРЫ ТЕЛА, ИНДЕКСЫ ТЕЛОСЛОЖЕНИЯ. 


\section{Л I T E P A T Y P A}

1. Хмельничий Л. М. Оцінка екстер'єру в системі селекції молочної худоби. Монографія / Л. М. Хмельничий. - Суми: ВВП «Мрія-1», 2007. - 260 с.

2. Ставецька Р. В. Ефективність проведення відбору корів української чорно-рябої молочної породи за екстер'єром / Р. В. Ставецька, Н. І. Клопенко // Вісник Житомирського національного агроекологічного університету. - 2013. - № 1. - Том 2 (35). - С.179-186.

3. Федорович $C$. I. Оцінка високопродуктивних корів української чорно-рябої молочної породи за екстер'єром і молочною продуктивністю / С. І. Федорович // Зоотехнічна наука: історія, проблеми, перспективи. Матеріали V міжнародної науково-практичної конференції. Кам'янець-Подільський, 2015. - С. 123-124.

4. Кузів M. I. Онтогенетичні та селекційно-біологічні закономірності формування молочної продуктивності чорно-рябої худоби західного регіону України: автореф. дис. на здобуття наук. ступеня доктора с.-г. наук: спец. 06.02.01 «Розведення та селекція тварин» / М. І. Кузів. - с. Чубинське Київської обл., 2018. - 40 с.

5. Лобода В. П. Лінійна класифікація корів української червоно-рябої молочної породи північно-східного регіону за екстер'єрним типом / В.П. Лобода // Вісник Сумського національного аграрного університету. Серія «Тваринництво». - 2014. - Вип.7(26). - С.46-50.

6. Прохоренко П. Голштинская порода и ее влияние на генетический прогресс продуктивности черно-пестрого скота европейских стран и Российской Федерации / П. Прохоренко // Молочное и мясное скотоводство. - 2013. - № 2. - С. 2-6.

7. Розведення сільськогосподарських тварин / [Басовський М. 3., Буркат В. П., Вінничук Д. Т. та ін.]. - Біла Церква, 2001. - 400 с.

8. Екстер'єр молочних корів: перспективи оцінки і селекції: монографія / [Сірацький Й. 3., Данилків Я. Н., Данилків О. М. та ін.]; за ред. Й. З. Сірацького, Є. І. Федорович. - К. : Науковий світ, 2001. - 146 с

9. Лакин Г. Ф. Биометрия: учебное пособие [для биол. спец. вузов] / Г. Ф. Лакин. - (4-е изд., перераб. и доп.). - М.: Высшая школа, 1990. - 352 с.

10. Програма селекції української чорно-рябої молочної породи великої рогатої худоби на 2003-2012 рр. / [Мельник Ю. Ф., Микитюк Д. М., Пищолка В. А. та ін.] - Київ, 2003. - 83 с.

11. Програма селекції української червоно-рябої молочної породи великої рогатої худоби на 2003-2012 роки / [Мельник Ю. Ф., Литовченко А. М., Білоус О. В. та ін.]. - Київ, 2003. $-77 \mathrm{c}$.

\section{References}

1. Khmelnychyi L. M. Exterior evaluation in the system of breeding of dairy cattle. Monograph, 2007, 260 p (in Ukrainian).

2. Stavetska R. V., Klopenko N. I. Efficiency of selection of cows of Ukrainian Black-andWhite milk breed by exteriors. Bulletin of Zhytomyr National Agroecological University, 2013, no 1, vol. (35), pp.179-186 (in Ukrainian).

3. Fedorovych Ye. I. Estimation of high-yielding cows of Ukrainian Black-and-White milk breed by exteriors and milk production. Zootechnical science: history, problems, perspectives. Materials of the V International Scientific and Practical Conference, 2015, pp. 123-124 (in Ukrainian).

4. Kuziv M. I. Ontogenetic and breeding-biological regularities of the formation of milk production of Black-and-White cattle in the western region of Ukraine. Manuscript copyright. Thesis for a Doktor's degree of Agricultural Sciences by profession 06.02.01 - Animal Selective and Breeding, Chubynske village, Kyiv district, 2018, 40 p (in Ukrainian). 
5. Loboda V. P. Linear classification of cows of Ukrainian Red-and-White breed of northeastern region by exterior type. Bulletin of the Sumy National Agrarian University. Animal Livestock Series, 2014, vol.7(26), pp.46-50 (in Ukrainian).

6. Prohorenko P. Holstein breed and its influence on the genetic progress of the productivity of black and variegated cattle in European countries and the Russian Federation. Dairy and Beef Cattle Breeding, 2013. no 2, pp. 2-6 (in Ukrainian).

7. Basovskyi M. Z., Burkat V. P., Vinnychuk D. T. , Kovalenko V. P., Kiva M. S., Ruban Yu. D., Rudyk I. A., Siratskyi Y. Z. Breeding of farm animals, 2001, 400 p (in Ukrainian).

8. Siratskyi Y. Z., Danylkiv Ya. N., Danylkiv O. M., Fedorovych Ye. I., Merkushyn V. V., Melnyk Yu. F., Chupryna O. P., Kadysh V. O., Liubynskyi O. I. Exterior of dairy cows: prospects for evaluation and selection: monograph, 2001, 146 p (in Ukrainian).

9. Lakin G. F. Biometrics: study guide, 1990. 352 p (in Russian).

10. Melnyk Yu. F., Mykytiuk D. M., Pyshcholka V. A., Lytovchenko A. M., Bilous O. V., Vyshnevskyi L. V., Kudriavska N. V., Pivinska H. I., Hubin O. O., Yefimenko M. Ya., Antonenko V. I., Havrylenko M. S., Kovalenko H. S., Kuzmenko I. I., Vasylkivskyi S. B., Podoba B. Ye., Siratskyi Y. Z., Fedorovych Ye. I., Sharan P. I., Bashchenko M. I., Tyshchenko I. V., Khmelnychyi L. M. Selection program of Ukrainian Black-and-White milk breed of cattle for 2003-2012 years. Kiev, 2003, 83 p (in Ukrainian).

11. Melnyk Yu. F., Lytovchenko A. M., Bilous O. V., Burkat V. P., Kruhliak A. P., Podoba B. Ye., Havrylenko M. S., Sharan P. I., Kruhliak O. V., Stoianov R. O., Kruhliak P. A., Kruhliak L. S., Bashchenko M. I., Yachnyk R. V., Ruban S. Yu. Program of selection of Ukrainian Red-and-White milk breed of cattle for 2003-2012 years. Kiev, 2003. 77 p (in Ukrainian).

Рецензент - Н. П. Мазур, д. с.-г. н., Інститут біології тварин НААН. 